\title{
Abundance, diversity and daily activity of terrestrial mammal and bird species in disturbed and undisturbed limestone habitats using camera trapping, Central Thailand
}

\author{
MANANYA PLA-ARD, WIPAVEE HOONHEANG, BUNYATHIPORN KAEWDEE, TARAPON PANGANTA, \\ KHWANRUTAI CHARASPET, NORASET KHOIESRI, PAANWARIS PAANSRI, PEMIKA KANKA, \\ YUWARAK CHANACHAI, JIDAPHA THONGBANTHUM, PHANITSUPHA BANGTHONG, \\ RONGLARP SUKMASUANG \\ Department of Forest Biology, Faculty of Forestry, Kasetsart University. 50 Phahonyothin Road, Chatuchak District, Bangkok 10900, Thailand.
} Tel.: +66-2-579-0176, Fax.: +66-2-942-8107, `email: mronglarp@gmail.com

Manuscript received: 16 July 2021. Revision accepted: 31 July 2021.

\begin{abstract}
Pla-ard M, Hoonheang W, Kaewdee B, Panganta T, Charaspet K, Khoiesri N, Paansri P, Kanka P, Chanachai Y, Thongbanthum J, Bangthong P, Sukmasuang R. 2021. Abundance, diversity and daily activity of terrestrial mammal and bird species in disturbed and undisturbed limestone habitats using camera trapping, Central Thailand. Biodiversitas 22: 3620-3631. This study on the abundance, diversity and daily activity of terrestrial mammal and bird species was conducted in the limestone mountainous area of Central Thailand, located on the east of Dong Phaya Yen-Khao Yai forest complex. Camera traps were placed in both habitats disturbed by limestone mining and undisturbed habitat areas. From the study, a total of 38 species of mammals and birds from 27 families in 13 orders were recorded, including 15 species of mammals from 6 orders, 12 families and 23 species of birds from 14 families in 7 orders. Fifteen species of mammals were recorded in the undisturbed area and 11 were recorded in the disturbed area, with the Malayan Pangolin, Small Indian Civet and Grey-bellied Squirrel found in the undisturbed area. However, the number of bird species in the limestone mining area was larger than in the undisturbed area. It was also found that there was no difference in the overall abundance and diversity of mammalian species between disturbed and undisturbed areas, which is not in accordance with the hypothesis. But in the case of wild birds, the relative abundance of wild birds was found to differ significantly between areas. A high number was found in the areas with mining activities, although there was no difference in the diversity index of the two areas. However, it was found that when the combined data was analyzed, there was a significant difference in the daily activity of both mammals and wild birds in both areas. Many rare wildlife species were recorded during this study, for example, the Malayan Pangolin, Serow, Northern Pig-tailed Macaque, Rufous Limestone-babbler, Golden Jackal, Leopard Cat, Large-toothed Ferret Badger, Small Asian Mongoose, Common Palm Civet, Small Indian Civet, Malayan Porcupine. The key measure proposed is to preserve some natural habitats within the areas with mining activities, as wildlife remains in the area.
\end{abstract}

Keywords: karstic habitat, species diversity, relative abundance, activity pattern, time partitioning

\section{INTRODUCTION}

Limestone or karst mountains are sedimentary rocks formed by the accumulation of carbonates from marine organisms, together with changes of the Earth's crust, a geological evolutionary process that has happened for millions of years )Clements et al. 2006). In Asia, Karstic habitat covers an area of approximately 8.35 million $\mathrm{km}^{2}$ )Grismer et al. 2021). Karst mountains of Southeast Asia cover an area of $460,000 \mathrm{~km}^{2}$ or $10 \%$ of the total area )Day and Urich 2000(. Limestone or karstic habitats are originally rare terrestrial ecosystems. The size of Thailand's limestone mountain topography still lacks actual research data. However, it was found that the limestone mountain areas are widely distributed, from the north, west, central, east and down to the south of Thailand, but are not connected together as a large mountain range. Large areas of connected limestone mountains are found in the Western Forest Complex and around the Dong Phaya Yen-Khao Yai Forest Complex )Latinne et al. 2011), especially on the east of the Dong Phaya Yen-Khao Yai forest complex which is a natural world heritage site and one of the most important limestone habitats )Clements et al. 2006).

Limestone mountains (Karstic habitat) are inhabited by many endemic living organisms including flora (Phutthai and Hughes 2017), wildlife and insects )Hughes 2017 (. They are also areas with regular new species records )Liu et al. 2015(, especially rodents )Latinne et al. 2011), bats )Balete et al. 2013), birds (e.g. Alström et al. 2010), reptiles )e.g. Luu et al. 2016, 2017; Hughes 2017; Nazarov et al. 2018; Grismer et al. 2018, 2021), amphibians )Dehling 2011), fishes, invertebrates (Haase and Schilthuizen 2007) and many species of insects (Grinang 2013). There are still many living organisms within the limestone mountains that have not yet been studied )Chung et al. 2014). This is why it is a very important area for biodiversity conservation. At the same time, the limestone mountains are heavily threatened from many factors, including the expansion of agricultural land along the plains between the valleys and along the waterways, the expansion of the community, 
construction of transport routes, drought conditions with water shortages during the dry season, forest fires and human activities within the area such as poaching, collecting forest products, logging and construction in the area )Woxvold et al. 2009; Lillo et al. 2019).

The significant threats to limestone mountain habitats arise from their use as feedstock for the cement industry, both for domestic construction and export. As well as the industrial sites within limestone mountains in various countries of Asia, one of the world's large cement industrial sites, especially in the People's Republic of China )Hughes 2017) which has the largest area of limestone mountain coverage in Asia. In Thailand, the allowance of the mining concessions accounts for approximately $20 \%$ of the total limestone mountain area (Latinne et al. 2011). The nature of making an industrial source is to open up the area, which severely threatens the survival of living creatures as well as this unique habitat (Hughes 2017).

The limestone mountain habitat of Saraburi Province is a part of the largest continuous limestone mountain range in Thailand (Latinne et al. 2011). It is also an important source of raw materials that have been constantly used in the cement industry for a long time. The cement concessionaire has carried out a project to restore natural resources in the area after the mining. The restoration includes soil amendment and planting trees, as well as protecting some areas for the preservation of local wild animals and plants (Siam Cement Group 2017) which follows the International Union for Conservation of Nature (IUCN) criteria (2014). However, there have been only a few follow-up studies.

Studies on the diversity, abundance and evenness of wildlife can indicate the direct response of wildlife to the environment ) Tu et al. 2020). There have been few studies on the diversity of wildlife in limestone mountain ranges using camera traps. There has never been a wildlife diversity study using camera traps in limestone mountain habitats that have not been previously disturbed by mining. The results of the study can therefore be used as information for area management, species and wildlife population conservation, a measure of their integrity, leading to the success of further operations in the area.

In this study, the main hypothesis is that, when considering the diversity, abundance and activity of the wildlife, there will be a difference in the response of wildlife between the limestone habitats disturbed by mining and undisturbed areas. Undisturbed areas are expected to have greater diversity and abundance of wildlife than disturbed areas. Also, the activities of wildlife, especially mammals, in disturbed areas change to avoid human activities. The results obtained, in addition to knowing the species diversity and the numbers of wildlife in limestone habitats from camera traps which have been very little studied, the activity patterns of the wildlife that relate to the environment in the limestone mountains can also be used for efficient environmental management, especially reducing the disturbance, to be suitable for the conservation of wildlife in limestone mountain habitats )Dias-Silva et al. 2018). The objectives of this study are: (i) To study the species and abundance of wildlife in the areas of the disturbed and undisturbed habitats, both combined and separate, and (ii) To study the activity patterns of the wildlife in the area, to understand the conditions of wildlife resources that still inhabit the limestone mountains, even though they are outside the protected area, for the benefit of proper conservation and restoration in the future.

\section{MATERIALS AND METHODS}

\section{Study area}

The study area was located in Kang Koi, Saraburi province following the eastern border of Dong Phaya YenKhao Yai Forest Complex, a world natural heritage site )UNESCO 2021), with a highway passing through between the study area and Dong Phaya Yen-Khao Yai Forest Complex. The study area was divided into two areas. The first area was an intact undisturbed limestone habitat covering an area of approximately $5.15 \mathrm{~km}^{2}$ located between $14^{\circ} 40^{\prime} 52.2^{\prime \prime}-14^{\circ} 40^{\prime} 40.8^{\prime \prime} \mathrm{N}$ and $101^{\circ} 05^{\prime} 51.7^{\prime \prime}-$ $101^{\circ} 06^{\prime} 38.0^{\prime \prime E}$ approximately. The second area was a limestone quarry with ongoing mining activities from 1969 until the present and having an area of approximately 4.12

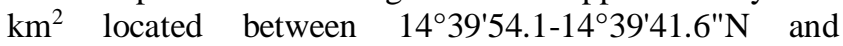
$101^{\circ} 02^{\prime} 58.7-101^{\circ} 03^{\prime} 25.6^{\prime \prime E}$ approximately )Siam Cement Group 2017). The study area and camera trap locations are shown in Figure 1.

The general condition of both study areas is limestone mountains with an elevation of 10-252 m above sea level and a slope of 35-70 degrees. Limestone vegetation is extremely diverse in community types and very rich in endemic taxa (Hua 2002) as with this study area many flora species is specific to the limestone forest ecology, for example, Phyllanthus mirabilis, Toona calcicole, Erythrina calcicole, Dracaena loureiroi, Dracaena kaweesakii, Cycas petrae, Santisukia kerrii, Toxicodendron calcicole, Ehretia laevis, Ficus anastomosans, Ficus glaberima, Ficus alongensis, Ficus pubipetiola, Mitrephora tomentosa, Garuga floribunda, etc. Shrub species found are for example Euphorbia antiquorum, Dracaena loureirin, Dracaena cochinchinensis, Dracaena jayniana, Dracaena kaweesakii, etc. )Department of National Parks, Wildlife and Plant Conservation 2018). In this limestone mountain study area, there have been reports of the presence of the Rufous Limestone-babbler (Turdinus calcicola) which is an endemic species of the Saraburi limestone mountain (BirdLife International 2021). This indicates the long evolutionary natural history of this limestone mountain study area with remnant populations of wild bird species in the ecosystem. 

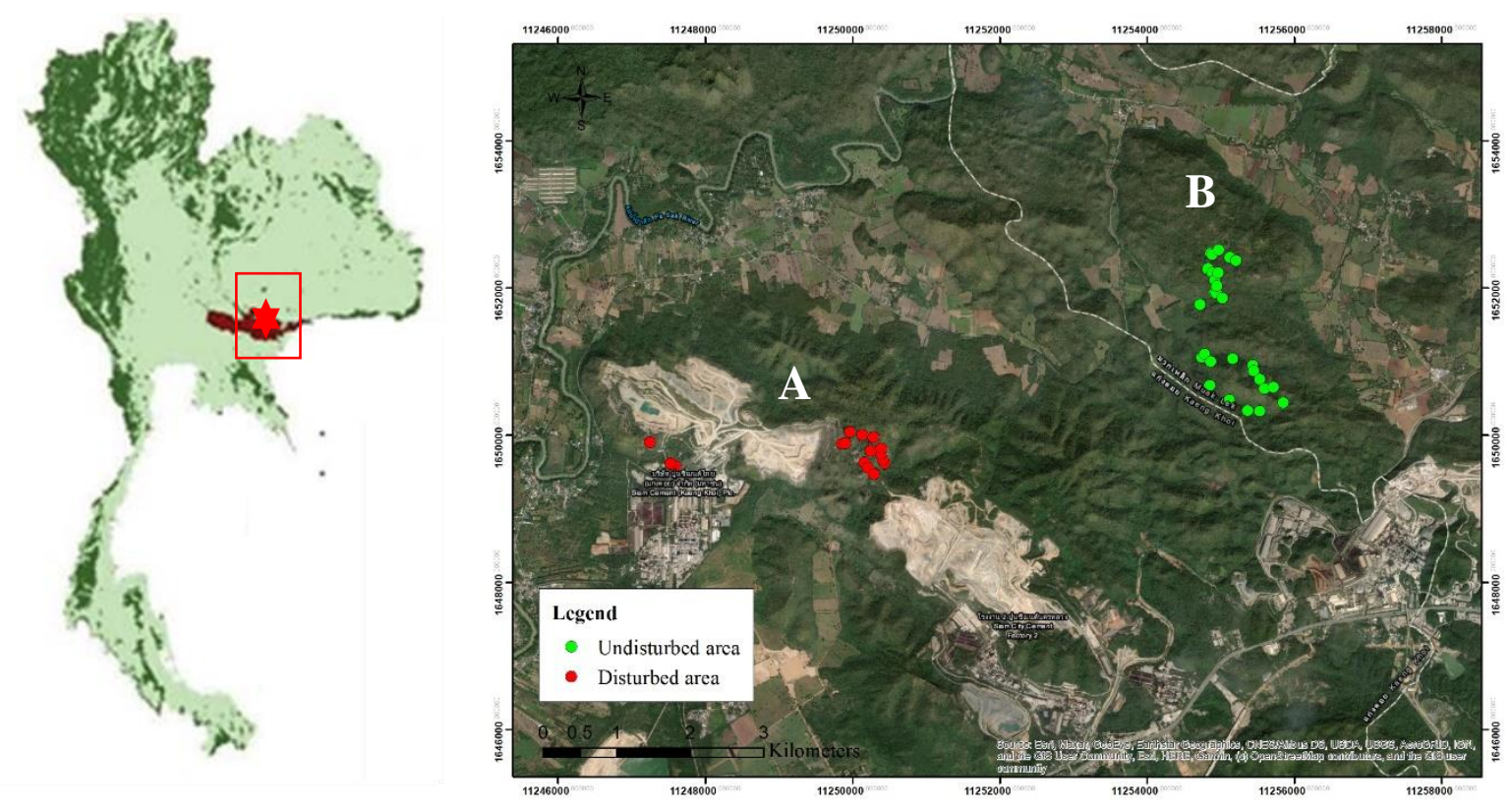

Figure 1. Map shows location of the study sites, red star, disturbed area (A) undisturbed area (B), and camera trap locations, red dots and green dots in each site in Kaeng Khoi District, Saraburi Province, Thailand. Source: Google Earth (2021)

The study area has a tropical savanna climate (Aw), following Köppen climate classification (Chen and Chen 2013), which has low precipitation and is dry. Based on the meteorological data of Saraburi province in the past 69 years, between 1951-2019, the seasons can be divided into 3 seasons including winter from mid-October to midFebruary, the hot season from mid-February to mid-May, with hot and humid weather and the hottest month being April and the rainy season starts from mid-May to midOctober. The month with the highest precipitation is September. The average annual temperature is around 28$30{ }^{\circ} \mathrm{C}$. The annual precipitation is between $1,200-1,400$ $\mathrm{mm}$ with an average rainfall of 70-90 days per year (Department of Meteorological 2020).

\section{Data collection}

Field surveys were performed in the forests of both study areas. The first area chosen for the camera trap survey study was the disturbed area, which was conducted during November 2015-September 2016. For the undisturbed area, the camera trap survey was performed during November 2019-September 2020 due to the difficult conditions of the area with rough limestone terrain and being hard to access by using automatic camera traps, Bushnell Trophy Cam HD Essential E2 12MP Trail Camera sets. After selecting the appropriate camera trap location for the wildlife survey, the cameras were deployed systematically by placing them approximately 100-200 meters apart. This was performed following the recommendations of Jansen et al. (2014) on carrying out sample plots for long-term forest ecology studies to intensively study the interactions of wildlife in the ecosystem, and human activities )Keim et al. 2019). Eight to twelve cameras were placed in each study trip. A total of 16 camera trap locations were studied in the disturbed study area and 24 in the undisturbed area, which is related to the size of the study area, adding up to a total of 40 locations. Photos were automatically captured when the sensor system detecting movement both during daytime and nighttime. The camera traps were placed over a period of 1 year in each area. This is consistent with Kays et al. (2020) who recommended that to monitor the diversity of wildlife within an area, a total of 4060 camera trap locations should be used throughout the study period.

The camera traps were placed approximately $30 \mathrm{~cm}$ above the ground and set to work 24 hours, with 10-second interval between triggers )Jansen et al. 2014(. The GPS locations of the camera traps and the environmental conditions of the area were recorded. Some locations were changed due to the disturbance of the cameras.

The cameras were serviced monthly by downloading data from the memory cards and changing batteries throughout the twelve-month duration. The cameras were first placed within the disturbed area with limestone mining activities and once the data collection in the first area was complete, they were then moved to the second area and deployed for another 12 months. The images were downloaded from the memory cards into the computer and classified using Camera Trap Manager )Zaragozi et al. 2015(. The data was then imported into the Microsoft Excel program for data analysis.

\section{Data analysis}

Species identification

Only clearly identifiable images with the date and time shown on the images were classified. The mammalian species recorded were identified following Lekagul and McNeely )1988( and the wild bird species were identified following Lekagul and Round (1991). The common name, scientific name, taxonomic order and conservation status according to the IUCN (2021) were examined. This study uses the selection criterion for the images recorded from 
the camera traps by selecting only the images that are independent of each other. The criteria for independence of animal images include: (1) Consecutive images of different animals, which may be the same or different species; (2) Consecutive images of the same animal, the same species with a time interval of more than 30 minutes and (3) Nonconsecutive images of the same animal or the same species )O'Brien et al. 2003(.

\section{Diversity and evenness indices}

The diversity of wildlife species was calculated using the Shannon-Weiner Index (H) )Krebs 2014( of each species and overall following the formula,

$$
\mathrm{H}=-\sum_{i=1}^{S} p_{i} \ln p_{i}
$$

Where: $p_{i}=\mathrm{S} / \mathrm{N}$

$\mathrm{S}=$ number of individuals of one species

$\mathrm{N}=$ total number of all individuals in the sample

In $=$ logarithm to base e

The evenness index (E) (Pielou 1966) was calculated using the following formula

$$
\mathrm{E}=\mathrm{H} / \mathrm{In} \mathrm{S}
$$

Where:

$\mathrm{H}=$ Shannon-Wiener diversity index

$\mathrm{S}=$ total number of species in the sample

To use as an index for measuring the diversity of mammals and wild bird species in each area and overall )Harisha and Hosetti 2009), the wildlife diversity index was then compared between the disturbed and undisturbed areas using the Mann-Whitney U test, at the significance level of $\mathrm{P}<0.05$.

\section{Relative abundance}

The relative abundance index (RAI) of each species recorded by the camera traps was calculated using the ratio between the presence of the image and the total number of trap nights, which is a widely used method e.g., according to the publications of Ouboter and Kadosoe (2016), Palmer et al. (2018) and Steinbeiser et al. (2019). The calculation uses the formula presented below.

$$
\text { Relative abundance }(\%)=\frac{\text { trap success } \times 100}{\text { trap night }}
$$

The \%RAI of each species were compared between the disturbed and the undisturbed limestone habitat area using the Mann-Whitney $U$ test, at the significance level of $\mathrm{P}<0.05$.

\section{Activity pattern}

The information on the overall wildlife activity and the activity period of each species obtained from the camera traps was summarized. The time period was divided into daytime from 06:01-17:59 and nighttime from 18:00-06:00. The values were used to generate graphs of the activity pattern of the wildlife species. The species were classified into 5 groups according to the time shown in the photograph )Kronfeld-Schor et al. 2013(. That is, if the number of images during the day is more than $85 \%$, that animal will be grouped as strongly diurnal. If the number of daytime images is between $61-84 \%$, it will be grouped as mostly diurnal. If the numbers of night and daytime images fall within $40-60 \%$, it will be grouped as cathemeral. If the number of nighttime images is between $61-84 \%$, it will be grouped as mostly nocturnal. If the number of images during the night was between $40-60 \%$, the animal was classified to belong to a group with activities that overlapped between day and night (cathemeral). And if the number of images during the night is more than $85 \%$, the animal will be grouped as strongly nocturnal (van Schaik and Griffiths 1996) (Table 1). The classification was done only on the species that were recorded more than 20 times (Cremonesi et al. 2021).

\section{Active time}

The analysis of the average active time of the wild animals were recorded by the camera traps from independent images) $O$ 'Brien et al. 2003) at 95\% confidence interval was performed with ORIANA version 4.02 program (Kovach Computing Services 2011). MardiaWatson-Wheeler Tests $U^{2}$ test )Mardia 1972) was used to test the difference of the time of presence between the 2 areas, at the significance level $\mathrm{P}<0.05$.

\section{RESULTS AND DISCUSSION}

\section{Mammals}

A total of 15 mammalian species from 6 orders, 12 families were recorded in the study area including Serow )Capricornis sumatraensis), Golden Jackal )Canis aureus), Northern Pig-tailed Macaque )Macaca nemestrina), Leopard Cat )Prionailurus bengalensis), Small Asian Mongoose )Herpestes javanicus), Malayan Porcupine )Hystrix brachyura), Large-toothed Ferret Badger )Melogale personata), Variable Squirrel )Callosciurus finlaysoni), Indochinese Ground Squirrel Menetes berdmorei), Northern Tree Shrew )Tupaia belangeri), Common Palm Civet )Paradoxurus hermaphroditus), Small Indian Civet (Viverricula indica), Malayan Pangolin (Manis javanica), Grey-bellied Squirrel (Callosciurus caniceps) and rodent species that could not be identified from the photographs. The species with the largest distribution when considering from the highest number of locations present are Northern Pig-tailed Macaque (97.5\%), Serow (85.0\%) followed by Common Palm Civet (52.5\%), Golden Jackal (52.0\%), Variable Squirrel, Malayan Porcupine and Small Indian Civet, in this order.

When calculating the overall diversity index of mammalian species, it was found that in the limestone habitat study area, the Shannon-Weiner Index was 2.10 and the evenness index was 3.18.

The relative abundance index (\%RAI) of the mammals was $26.96 \%$. The species with the highest abundance was the Northern Pig-tailed Macaque with the value of $6.47 \%$, 
followed by Serow )6.40\%), Variable Squirrel (3.22\%), Indochinese Ground Squirrel (2.95\%), Golden Jackal $(2.03 \%)$ and Small Indian Civet $(1.90 \%)$. From the species of mammals recorded in this study, one species: the Malayan Pangolin, is categorized as critically endangered and two species including serow and Northern Pig-tailed Macaque are categorized as vulnerable. Detailed information is shown in Table 1.

\section{Wild birds}

From the study, 23 species of wild birds from 14 families, 7 orders were recorded including Red Junglefowl (Gallus gallus), Eastern spotted Dove (Streptopelia chinensis), Blue-winged Pitta (Pitta moluccensis), Greycapped Emerald Dove (Chalcophaps indica), Whiterumped Shama (Kittacincla malabarica), Greater Coucal (Centropus sinensis), White-crested Laughingthrush (Garrulax leucolophus), Oriental Honey-buzzard (Pernis ptilorhynchus), Shikra (Accipiter badius), Black-capped Bulbul (Pycnonotus melanicterus), Red-wattled Lapwing (Vanellus indicus), Blue Rock-thrush (Monticola solitarius), Malayan Night-heron (Gorsachius melanolophus), Rufous Limestone-babbler (Turdinus calcicola), Black Drongo (Dicrurus macrocercus), Streakeared Bulbul (Pycnonotus blanfordi), Sooty-headed Bulbul (Pycnonotus aurigaster), Blue Whistling-thrush (Myophonus caeruleus), Lesser Necklaced Laughingthrush (Garrulax monileger), Common Hoopoe (Upupa epops), Asian Brown Flycatcher (Muscicapa dauurica), Rackettailed Treepie (Crypsirina temia) and Crested Goshawk (Accipiter trivirgatus).

When calculating the overall diversity index of the wild birds in the limestone mountain study area, it was found that the Shannon-Weiner Index was 2.65 and the evenness index was 2.08.

From the 23 species of birds recorded by the camera traps, the \%RAI of each species from high to low included Red Junglefowl (3.20\%), Eastern Spotted Dove (1.40\%), Blue-winged Pitta and Grey-capped Emerald dove (0.44\%), White-rumped Shama (0.32\%), Greater Coucal $(0.27 \%)$, White-crested Laughing Thrush $(0.25 \%)$, Oriental Honeybuzzard $(0.22 \%)$, Shikra $(0.22 \%)$, Black-capped Bulbul $(0.22 \%)$, Rufous Limestone-babbler $(0.06 \%)$, etc. The distribution of birds from high to low for example are Red Junglefowl (65.0\%), Grey-capped Emerald dove (25\%), White-crested Laughing Thrush (22.5\%), White-rumped Shama (20.0\%), The Rufous Limestone-babbler, which is an endemic species, was found to have a $5.0 \%$ distribution.

From the wild birds recorded in this study, 22 species are listed in the least concern category and one, the Rufous Limestone-babbler is categorized as vulnerable as shown in Table 2.

\section{Comparison between the disturbed and undisturbed habitat \\ Mammals}

Results of the study from dividing the study area according to the disturbance characteristics of the limestone mountain area showed that, in the habitat undisturbed from limestone mining activities, 15 species of mammals were recorded. The important species, for example, are Serow, Northern Pig-tailed Macaque, Malayan Pangolin, Golden Jackal, Leopard Cat, Largetoothed Ferret Badger and Small Indian Civet. The species found only in the undisturbed habitat include the Small Indian Civet, Malayan Pangolin and Grey-bellied Squirrel. The Shannon-Wiener index was 2.05 , the species evenness index was 2.85 and the \%RAI was $29.31 \%$.

Meanwhile, in the area disturbed by limestone mining activities, 12 species of mammals were recorded which were the same species as recorded in the undisturbed area. The Shannon-Wiener index was 1.89 and the species evenness index was 3.77. Comparison of the diversity of wild mammals between the undisturbed and disturbed areas, using the Mann-Whitney $\mathrm{U}$ test, showed that there was no significant difference ) $\mathrm{Z}-0.70753, \mathrm{P}=0.4777$ ).

The overall \%RAI of wildlife was 24.64. When comparing the \%RAI of the undisturbed and disturbed areas using the Mann-Whitney $U$ test, it was found that there was no significant difference between the two areas ) $\mathrm{Z}=1.73, \mathrm{P}=.09$ ). This means that even in limestone habitats with mining activities, the abundance of wildlife is still as rich as in the undisturbed or natural areas.

\section{Wild birds}

A total of 19 species of wild birds were found in the disturbed area and 11 species in the undisturbed area. The species found only in the undisturbed area were the Oriental Honey-buzzard, Racket-tailed Treepie, Malayan Night Heron and Common Hoopoe. The overall \%RAI of the birds in the disturbed area was $8.70 \%$, while the \% RAI of the birds in the undisturbed area was $6.20 \%$, slightly lower than the disturbed area. The Rufous Limestonebabbler, which is an important endemic species, was found only in the disturbed area. This shows the importance of conserving the area, even though limestone mining concessions are given.

When comparing the \%RAI between the undisturbed and the disturbed area using the Mann-Whitney U test, it was found that there was a significant difference between the two areas $(\mathrm{Z}=-2.19692, \mathrm{P}=0.0278)$. This means that wild birds species use the limestone areas even with mining activities, especially the ground foraging species.

Table 1. Activity pattern classification of the animals based on $\%$ number of images during day and night times gained from camera trap data.

\begin{tabular}{lclc}
\hline $\begin{array}{l}\text { Activity } \\
\text { pattern }\end{array}$ & \multicolumn{2}{c}{$\%$ Number of images during day and night } \\
\cline { 2 - 4 } & $\mathbf{4 0 - 6 0 \%}$ & $\mathbf{6 1 - 8 4 \%}$ & \multicolumn{1}{c}{$\mathbf{8 5 \%}$} \\
\hline \multirow{2}{*}{$\begin{array}{l}\text { Day time } \\
\text { Nighttime }\end{array}$} & $\begin{array}{l}\text { Cathemeral } \\
\text { Cathemeral }\end{array}$ & $\begin{array}{l}\text { Mostly diurnal } \\
\text { Costly nocturnal }\end{array}$ & $\begin{array}{l}\text { Strongly diurnal } \\
\text { Strongly nocturnal }\end{array}$
\end{tabular}


Table 2. The abundance of mammals and wild birds found in the limestone mountain area of Saraburi province, Thailand from 40 camera trap locations with a total of 6,308 trap nights

\begin{tabular}{|c|c|c|c|c|c|}
\hline \multirow{2}{*}{ Common name } & \multirow{2}{*}{ Scientific name } & \multirow{2}{*}{ IUCN (2021) } & \multicolumn{3}{|c|}{ Limestone study area } \\
\hline & & & NOP & NOL )\%) & $\%$ RAI \\
\hline \multicolumn{6}{|l|}{ Mammalia } \\
\hline \multicolumn{6}{|l|}{ Order Artiodactyla } \\
\hline \multicolumn{6}{|l|}{ Family Bovidae } \\
\hline Serow & Capricornis sumatraensis & VU & 404 & $34(85.0)$ & 6.40 \\
\hline \multicolumn{6}{|l|}{ Order Carnivora } \\
\hline \multicolumn{6}{|l|}{ Family Canidae } \\
\hline Golden Jackal & Canis aureus & $\mathrm{LC}$ & 128 & $21(52.5)$ & 2.03 \\
\hline \multicolumn{6}{|l|}{ Family Felidae } \\
\hline Leopard Cat & Prionailurus bengalensis & $\mathrm{LC}$ & 20 & $13(32.5)$ & 0.32 \\
\hline \multicolumn{6}{|l|}{ Family Herpestidae } \\
\hline Small Asian Mongoose & Herpestes javanicus & $\mathrm{LC}$ & 31 & $16(40.0)$ & 0.49 \\
\hline \multicolumn{6}{|l|}{ Family Mustelidae } \\
\hline Large-toothed Ferret Badger & Melogale personata & $\mathrm{LC}$ & 2 & $2(5.0)$ & 0.03 \\
\hline \multicolumn{6}{|l|}{ Family Viverridae } \\
\hline Common Palm Civet & Paradoxurus hermaphroditus & $\mathrm{LC}$ & 90 & $21(52.5)$ & 1.43 \\
\hline Small Indian Civet & Viverricula indica & $\mathrm{LC}$ & 120 & $16(40.0)$ & 1.90 \\
\hline \multicolumn{6}{|l|}{ Order Primate } \\
\hline Family Cercopithecidae & & & & & \\
\hline Northern Pig-tailed Macaque & Macaca leonina & VU & 408 & $35(87.5)$ & 6.47 \\
\hline Order Rodentia & & & & & \\
\hline Family Muridae & & & & & \\
\hline Rat & Murid spp. & - & 26 & $7(17.5)$ & 0.41 \\
\hline Family Hystricidae & & & & & \\
\hline Malayan Porcupine & Hystrix brachyura & $\mathrm{LC}$ & 58 & $16(40.0)$ & 0.92 \\
\hline Family Sciuridae & & & & & \\
\hline Variable Squirrel & Callosciurus finlaysoni & $\mathrm{LC}$ & 203 & $20(50.0)$ & 3.22 \\
\hline Indochinese Ground Squirrel & Menetes berdmorei & $\mathrm{LC}$ & 186 & $16(40.0)$ & 2.95 \\
\hline Grey-bellied Squirrel & Callosciurus caniceps & - & 7 & $5(12.5)$ & 0.11 \\
\hline Order Scandentia & & & & & \\
\hline Family Tupaiidae & & & & & \\
\hline Northern Treeshrew & Tupaia belangeri & $\mathrm{LC}$ & 16 & $5(12.5)$ & 0.25 \\
\hline Order Pholidota & & & & & \\
\hline Family Manidae & & & & & \\
\hline Malayan Pangolin & Manis javanica & $\mathrm{CR}$ & 2 & $2(5.0)$ & 0.03 \\
\hline Wild birds & & & & & \\
\hline Order Galliformes & & & & & \\
\hline Family Phasianidae & & & & & \\
\hline Red Junglefowl & Gallus gallus & $\mathrm{LC}$ & 202 & $26(65.0)$ & 3.20 \\
\hline Order Passeriformes & & & & & \\
\hline Family Pittidae & & & & & \\
\hline Blue-winged Pitta & Pitta moluccensis & $\mathrm{LC}$ & 28 & $3(7.5)$ & 0.44 \\
\hline Family Pycnonotidae & & & & & \\
\hline Streak-eared Bulbul & Pycnonotus blanfordi & $\mathrm{LC}$ & 3 & $1(2.5)$ & 0.05 \\
\hline Sooty-headed Bulbul & Pycnonotus aurigaster & $\mathrm{LC}$ & 2 & $1(2.5)$ & 0.03 \\
\hline Black-capped Bulbul & Pycnonotus melanicterus & $\mathrm{LC}$ & 6 & $3(7.5)$ & 0.10 \\
\hline Family Leiothrichidae & & & & & \\
\hline White-crested Laughingthrush & Garrulax leucolophus & $\mathrm{LC}$ & 16 & $9(22.5)$ & 0.25 \\
\hline Lesser Necklaced Laughingthrush & Garrulax monileger & $\mathrm{LC}$ & 2 & $2(5.0)$ & 0.03 \\
\hline Family Muscicapidae & & & & & \\
\hline White-rumped Shama & Kittacincla malabarica & $\mathrm{LC}$ & 20 & $8(20.0)$ & 0.32 \\
\hline Blue Rock-thrush & Monticola solitarius & $\mathrm{LC}$ & 5 & $3(7.5)$ & 0.08 \\
\hline Asian Brown Flycatcher & Muscicapa dauurica & $\mathrm{LC}$ & 1 & $1(2.5)$ & 0.02 \\
\hline Blue Whistling-thrush & Myophonus caeruleus & $\mathrm{LC}$ & 2 & $2(5.0)$ & 0.03 \\
\hline Family Pellorneidae & & & & & \\
\hline Rufous Limestone-babbler & Turdinus calcicola & VU & 4 & $2(5.0)$ & 0.06 \\
\hline Family Dicruridae & & & & & \\
\hline Black Drongo & Dicrurus macrocercus & $\mathrm{LC}$ & 4 & $1(2.5)$ & 0.06 \\
\hline Family Corvidae & & & & & \\
\hline Racket-tailed Treepie & Crypsirina temia & $\mathrm{LC}$ & 1 & $1(2.5)$ & 0.02 \\
\hline Order Columbidae & & & & & \\
\hline Family Columbidae & & & & & \\
\hline Grey-capped Emerald Dove & Chalcophaps indica & $\mathrm{LC}$ & 28 & $10(25.0)$ & 0.44 \\
\hline Eastern Spotted Dove & Streptopelia chinensis & $\mathrm{LC}$ & 88 & $4(10.0)$ & 1.40 \\
\hline
\end{tabular}




\begin{tabular}{|c|c|c|c|c|c|}
\hline \multicolumn{6}{|l|}{ Family Cuculidae } \\
\hline Greater coucal & Centropus sinensis & LC & 17 & $4(10.0)$ & 0.27 \\
\hline \multirow{2}{*}{\multicolumn{6}{|c|}{ Order Charadriiformes }} \\
\hline & & & & & Family Charadriidae \\
\hline Red-wattled Lapwing & Vanellus indicus & $\mathrm{LC}$ & 6 & $1(2.5)$ & 0.10 \\
\hline \multicolumn{6}{|l|}{ Order Accipitriformes } \\
\hline \multicolumn{6}{|l|}{ Family Accipitridae } \\
\hline Crested Goshawk & Accipiter trivirgatus & $\mathrm{LC}$ & 1 & $1(2.5)$ & 0.02 \\
\hline Oriental Honey-buzzard & Pernis ptilorhynchus & $\mathrm{LC}$ & 14 & $3(7.5)$ & 0.22 \\
\hline Shikra & Accipiter badius & $\mathrm{LC}$ & 14 & $1(2.5)$ & 0.22 \\
\hline \multicolumn{6}{|l|}{ Oder Pelecaniformes } \\
\hline \multicolumn{6}{|l|}{ Family Ardeidae } \\
\hline Malayan Night-heron & Gorsachius melanolophus & $\mathrm{LC}$ & 5 & $2(5.0)$ & 0.08 \\
\hline \multicolumn{6}{|l|}{ Order Bucerotiformes } \\
\hline \multicolumn{6}{|l|}{ Family Upupidae } \\
\hline Common Hoopoe & Upupa epops & $\mathrm{LC}$ & 2 & $2(5.0)$ & 0.03 \\
\hline & Sum & & 471 & 91 & $\mathbf{7 . 4 7}$ \\
\hline
\end{tabular}

Note: NOP: number of photos, NOL = number of camera trap locations found, RAI: relative abundance index

When considering the diversity of wild birds in the undisturbed habitat. The diversity index calculated with the Shannon-Weiner index was 1.2083 , while the evenness of the species in the area following the species evenness index was 1.8851. And in the disturbed habitat, the ShannonWeiner index was 2.1412 and the species evenness index was 1.8406 . Results from the different test on the diversity of birds in the undisturbed and disturbed habitat using the Mann-Whitney U test showed no difference between the two areas )Z-0.12911, $\mathrm{P}=0.89656$ ). Details are shown in Tables 3-4.

\section{Activity pattern}

The activity patterns were considered in the mammalian species, which had more than 20 images recorded by camera traps. The species were categorized into 4 groups following their activity pattern which are: (i) Strongly nocturnal including Common Palm Civet, Small Indian Civet and Malayan Porcupine; (ii) Mostly nocturnal including Serow, Golden Jackal and Leopard Cat; (iii) Mostly diurnal including Indochinese Ground Squirrel and (iv) Strongly diurnal including Small Asian Mongoose, Northern Pig-tailed Macaque and Variable Squirrel.

When compared between the undisturbed and disturbed areas, it was found that the overall activity in both areas was mostly nocturnal, with variation in some species. For example, the Serows in the disturbed area have mostly nocturnal activities due to the avoidance of human activities, whereas in the undisturbed area, their activities are cathemeral, as there is no human disturbance during the daytime.

Twenty-three species of ground foraging birds were recorded in this study, all of which were recorded during the daytime. Therefore, the activity patterns of all species of wild birds were strongly diurnal, with the exception of the Malayan Night Heron, which had a total of 5 images recorded showing the activity pattern to be cathemeral, as shown in Table 4.

\section{Difference in the time of presence}

When considering the comparison of the average activity time of some species of mammals and Red
Junglefowl, a ground foraging bird species with enough images to test the difference between undisturbed and disturbed habitat, it was found that there was no difference in the activity cycle of the Small Indian Mongoose, Common Palm Civet, Leopard Cat and Red Junglefowl between the two areas. Although the differences could not be considered from the classified time of presence in both areas when considering only the activity patterns, as shown in Table 5, when the overall data was analyzed, it was found that the time-of-presence of mammals and wild birds recorded from the camera traps in both areas were significantly different )Mardia-Watson-Wheeler Tests $\mathrm{P}<0.01$ ), as shown in Table 6.

\section{Discussion}

Camera traps enable photographic data of mammals and birds in remote areas. They can record images at a natural recording rate, which cannot be carried out with direct observation from the researcher, especially in hard-to-reach areas such as in the middle of the limestone mountains (Cloyed et al. 2017). Results from this study on the diversity of mammals and wild birds in the limestone mountains show we were able to record 15 species of mammals from 6 orders with 12 families and 23 species of wild birds from 14 families in 7 orders, adding up to a total of 38 wildlife species from 27 families and 13 orders. This result is similar to the study by Mo et al. (2019) who studied mammals and birds in Jianfengling District, Hainan Island and reported 15 species of mammals and 33 species of birds. Shi et al. (2017) conducted a study using 83 camera trap locations with 10,961 trap days in Wolong National Nature Reserve, Sichuan Province, China during 2014-2016 and found 32 species of mammals and 59 species of birds. Sukmasuang et al. (2020) reported 23 species of mammals and 10 species of wild birds from camera trap surveys in 21 locations with 3,172 trap nights along the highway that passes through Khao Yai and Thap Lan National Parks. 
Table 3. The abundance of mammals and wild birds found in the limestone mountain concession area at Kaeng Khoi District, Saraburi Province from 24 camera trap locations with a total of 3,121 traps nights in the undisturbed natural habitat and 16 camera trap locations, 3,187 trap nights in the limestone mining area

\begin{tabular}{|c|c|c|c|c|c|c|c|c|}
\hline \multirow{2}{*}{ Common name } & \multicolumn{4}{|c|}{ Undisturbed limestone } & \multicolumn{4}{|c|}{ Disturbed limestone } \\
\hline & NOP & NOL $(\%)$ & $\%$ RAI & -pi ln pi & NOP & NOL $(\%)$ & \% RAI & -pi ln pi \\
\hline \multicolumn{9}{|l|}{ Mammalia } \\
\hline Serow & 128 & $19(79)$ & 4.1 & 0.275 & 276 & $15(94)$ & 8.66 & 0.368 \\
\hline Northern Pig-tailed Macaque & 253 & $22(92)$ & 8.11 & 0.355 & 155 & $13(81)$ & 4.86 & 0.32 \\
\hline Indochinese Ground Squirrel & 91 & $9(37)$ & 2.92 & 0.230 & 95 & $7(44)$ & 2.98 & 0.255 \\
\hline Variable Squirrel & 116 & $12(50)$ & 3.72 & 0.262 & 87 & $8(50)$ & 2.73 & 0.244 \\
\hline Common Palm Civet & 14 & $9(37)$ & 0.45 & 0.064 & 76 & $12(75)$ & 2.38 & 0.226 \\
\hline Rat & 3 & $3(12)$ & 0.1 & 0.019 & 23 & $4(25)$ & 0.72 & 0.103 \\
\hline Small Asian Mongoose & 13 & $10(42)$ & 0.42 & 0.061 & 18 & $6(37)$ & 0.56 & 0.086 \\
\hline Malayan Porcupine & 41 & $10(42)$ & 1.31 & 0.139 & 17 & $6(37)$ & 0.53 & 0.083 \\
\hline Golden Jackal & 113 & $16(67)$ & 3.62 & 0.258 & 15 & $5(31)$ & 0.47 & 0.076 \\
\hline Northern Treeshrew & 1 & $1(4)$ & 0.03 & 0.007 & 15 & $4(25)$ & 0.47 & 0.076 \\
\hline Leopard Cat & 12 & $8(33)$ & 0.38 & 0.056 & 8 & $5(31)$ & 0.25 & 0.047 \\
\hline Large-toothed Ferret Badger & 1 & $1(4)$ & 0.03 & 0.007 & 1 & $1(6)$ & 0.03 & 0.008 \\
\hline Small Indian Civet & 120 & $16(67)$ & 3.84 & 0.266 & 0 & 0 & 0 & 0 \\
\hline Malayan Pangolin & 2 & $2(8)$ & 0.06 & 0.013 & 0 & 0 & 0 & 0 \\
\hline Grey-bellied Squirrel & 7 & $5(20)$ & 0.22 & 0.037 & 0 & 0 & 0 & 0 \\
\hline Sum & 915 & & 29.31 & 2.05 & 786 & & 24.64 & 1.89 \\
\hline \multicolumn{9}{|l|}{ Aves } \\
\hline Eastern Spotted Dove & 1 & $1(4)$ & 0.03 & 0.026 & 87 & $3(19)$ & 2.73 & 0.364 \\
\hline Red Junglefowl & 133 & $17(70)$ & 4.26 & 0.258 & 69 & $9(56)$ & 2.17 & 0.346 \\
\hline Blue-winged Pitta & 0 & 0 & 0 & 0 & 28 & $3(19)$ & 0.88 & 0.232 \\
\hline Greater Coucal & 2 & $2(8)$ & 0.06 & 0.045 & 15 & $2(12)$ & 0.47 & 0.158 \\
\hline Shikra & 0 & 0 & 0 & 0 & 14 & $1(6)$ & 0.44 & 0.151 \\
\hline Grey-capped Emerald Dove & 17 & $6(25)$ & 0.54 & 0.213 & 11 & $4(24)$ & 0.35 & 0.129 \\
\hline White-rumped Shama & 10 & $5(20)$ & 0.32 & 0.153 & 10 & $3(19)$ & 0.31 & 0.119 \\
\hline White-crested Laughingthrush & 8 & $5(20)$ & 0.26 & 0.133 & 8 & $4(25)$ & 0.25 & 0.102 \\
\hline Black-capped Bulbul & 0 & 0 & 0 & 0 & 6 & $3(19)$ & 0.19 & 0.084 \\
\hline Red-wattled Lapwing & 0 & 0 & 0 & 0 & 6 & $1(6)$ & 0.19 & 0.084 \\
\hline Blue Rock-thrush & 0 & 0 & 0 & 0 & 5 & $3(19)$ & 0.16 & 0.073 \\
\hline Rufous Limestone-babbler & 0 & 0 & 0 & 0 & 4 & $2(12)$ & 0.13 & 0.063 \\
\hline Black Drongo & 0 & 0 & 0 & 0 & 4 & $1(6)$ & 0.13 & 0.063 \\
\hline Streak-eared Bulbul & 0 & 0 & 0 & 0 & 3 & $1(6)$ & 0.09 & 0.047 \\
\hline Sooty-headed Bulbul & 0 & 0 & 0 & 0 & 2 & $1(6)$ & 0.06 & 0.034 \\
\hline Lesser Necklaced Laughingthrush & 0 & 0 & 0 & 0 & 2 & $2(12)$ & 0.06 & 0.034 \\
\hline Asian Brown Flycatcher & 0 & 0 & 0 & 0 & 1 & $1(6)$ & 0.03 & 0.02 \\
\hline Blue Whistling Thrush & 1 & $1(4)$ & 0.03 & 0.026 & 1 & $1(6)$ & 0.03 & 0.02 \\
\hline Crested Goshawk & 0 & 0 & 0 & 0 & 1 & $1(6)$ & 0.03 & 0.02 \\
\hline Oriental Honey-buzzard & 14 & $3(12)$ & 0.45 & 0.19 & 0 & 0 & 0 & 0 \\
\hline Racket-tailed Treepie & 1 & $1(4)$ & 0.03 & 0.026 & 0 & 0 & 0 & 0 \\
\hline Malayan Night Heron & 5 & $2(8)$ & 0.16 & 0.094 & 0 & 0 & 0 & 0 \\
\hline Common Hoopoe & 2 & $2(8)$ & 0.06 & 0.045 & 0 & 0 & 0 & 0 \\
\hline Sum & 194 & & 6.20 & 1.21 & 277 & & 8.70 & 2.14 \\
\hline
\end{tabular}

Notes: NOP: Number of photo; NOL: Number of locations; RAI: Relative abundance

Table 4. Comparison of the number of species, diversity index and evenness index of the mammals and ground foraging birds recorded by the camera traps between the undisturbed and disturbed limestone habitats in Saraburi province, Thailand

\begin{tabular}{llll}
\hline & $\begin{array}{l}\text { Undisturbed } \\
\text { habitat }\end{array}$ & $\begin{array}{l}\text { Disturbed } \\
\text { habitat }\end{array}$ & $\begin{array}{l}\text { Combined } \\
\text { data }\end{array}$ \\
\hline Mammalian diversity & & & \\
$\quad$ Number of species & 15 & 12 & 15 \\
$\quad$ Shannon-Weiner index & 2.05 & 1.89 & 2.10 \\
$\quad$ Evenness index & 2.85 & 3.77 & 3.18 \\
Terrestrial aves diversity & & & \\
$\quad$ Number of species & 11 & 19 & 23 \\
$\quad$ Shannon-Weiner index & 1.21 & 2.14 & 2.65 \\
Evenness index & 1.88 & 1.84 & 2.08 \\
\hline
\end{tabular}

The results from this study show that there was no significant difference in the \%RA and the Shanon-Weiner index of wild mammals between the disturbed and undisturbed areas. This means that there is no difference in the importance of conserving the wildlife habitat, whether it be an area with limestone mining activity. However, when considering the mammalian diversity index, it was found that the undisturbed area was higher for both the Shannon-Weiner index and the Evenness index but did not significant difference, which indicates the importance of the undisturbed area for the preservation of wild mammals, especially rare wildlife that are endangered or critically endangered. 
Table 5. Comparison of the activity patterns of mammals and wild birds in the limestone mountain concession area between undisturbed and disturbed areas recorded by camera traps in central of Thailand

\begin{tabular}{|c|c|c|c|c|c|c|c|c|c|}
\hline \multirow{2}{*}{ Species } & \multicolumn{3}{|c|}{ Total Number of independent photos } & \multicolumn{3}{|c|}{ No. photos during daytime $(\%)$} & \multicolumn{2}{|l|}{ Activity pattern } & \multirow[b]{2}{*}{ Combined } \\
\hline & Undisturbed & Disturbed & Combined & Undisturbed & Disturbed & Combined & Undisturbed & Disturbed & \\
\hline \multicolumn{10}{|l|}{ Mammalian species } \\
\hline Northern Pig-tailed Macaque & 253 & 155 & 408 & 232(92) & 153(99) & $385(94)$ & SD & SD & SD \\
\hline Serow & 128 & 276 & 404 & $51(40)$ & $42(15)$ & $93(23)$ & $\mathrm{C}$ & SN & $\mathrm{MN}$ \\
\hline Variable Squirrel & 116 & 87 & 203 & 103(89) & $81(93)$ & 184(90) & SD & SD & SD \\
\hline Indochinese Ground Squirrel & 91 & 95 & 186 & $83(91)$ & $69(73)$ & $152(81)$ & $\mathrm{SD}$ & MD & MD \\
\hline Golden Jackal & 113 & 15 & 128 & $42(37)$ & $5(33)$ & $47(36)$ & MN & MN & MN \\
\hline Small Indian Civet & 120 & 0 & 120 & $5(4)$ & $0(0)$ & $5(4)$ & SN & - & SN \\
\hline Common Palm Civet & 14 & 76 & 90 & $0(0)$ & $0(0)$ & $0(0)$ & $\mathrm{SN}$ & $\mathrm{SN}$ & $\mathrm{SN}$ \\
\hline Malayan Porcupine & 41 & 17 & 58 & $1(2)$ & $0(0)$ & 1(1) & SN & SN & SN \\
\hline Small Asian Mongoose & 13 & 18 & 31 & $11(85)$ & $16(89)$ & $27(87)$ & SD & SD & SD \\
\hline Rat & 3 & 23 & 26 & $0(0)$ & $1(4)$ & $1(3)$ & Not classified & Not classified & Not classified \\
\hline Leopard Cat & 12 & 8 & 20 & $5(42)$ & 1(13) & $6(30)$ & $\mathrm{C}$ & SN & MN \\
\hline Northern Treeshrew & 1 & 15 & 16 & $0(0)$ & $15(100)$ & $15(93)$ & Not classified & Not classified & Not classified \\
\hline Grey-bellied Squirrel & 7 & 0 & 7 & $7(100)$ & $0(0)$ & $7(100)$ & Not classified & Not classified & Not classified \\
\hline Malayan Pangolin & 2 & 0 & 2 & $1(50)$ & $0(0)$ & $1(50)$ & Not classified & Not classified & Not classified \\
\hline Large-toothed Ferret Badger & 1 & 1 & 2 & $0(0)$ & $0(0)$ & $0(0)$ & Not classified & Not classified & Not classified \\
\hline \multirow{2}{*}{\multicolumn{10}{|c|}{ Aves species }} \\
\hline & & & & & & & & & \\
\hline Red Junglefowl & 133 & 69 & 202 & $115(86)$ & $61(88)$ & $176(87)$ & SD & SD & SD \\
\hline Eastern Spotted Dove & 1 & 87 & 88 & $1(100)$ & $83(100)$ & $84(95)$ & $\mathrm{SD}$ & $\mathrm{SD}$ & SD \\
\hline Grey-capped Emerald Dove & 17 & 11 & 28 & $17(100)$ & $11(100)$ & $28(100)$ & $\mathrm{SD}$ & SD & SD \\
\hline Blue-winged Pitta & 0 & 28 & 28 & $0(0)$ & $28(100)$ & $28(100)$ & SD & SD & SD \\
\hline White-rumped Shama & 10 & 10 & 20 & $8(80)$ & $10(80)$ & $18(90)$ & SD & SD & SD \\
\hline Greater Coucal & 2 & 15 & 17 & $2(100)$ & $15(100)$ & $17(100)$ & SD & SD & SD \\
\hline White-crested Laughingthrush & 8 & 8 & 16 & $6(75)$ & $8(100)$ & $14(87)$ & SD & SD & SD \\
\hline Oriental Honey-buzzard & 14 & 0 & 14 & $14(14)$ & $0(0)$ & $14(100)$ & $\mathrm{SD}$ & $\mathrm{SD}$ & SD \\
\hline Shikra & 0 & 14 & 14 & $0(0)$ & $11(79)$ & $11(78)$ & Not classified & Not classified & Not classified \\
\hline Black-capped Bulbul & 0 & 6 & 6 & $0(0)$ & $6(100)$ & $6(100)$ & Not classified & Not classified & Not classified \\
\hline Red-wattled Lapwing & 0 & 6 & 6 & $0(0)$ & $6(100)$ & $6(100)$ & Not classified & Not classified & Not classified \\
\hline Malayan Night Heron & 5 & 0 & 5 & $3(60)$ & $0(0)$ & $3(60)$ & Not classified & Not classified & Not classified \\
\hline Blue Rock-thrush & 0 & 5 & 5 & $0(0)$ & $5(0)$ & $5(100)$ & Not classified & Not classified & Not classified \\
\hline Limestone Wren Babbler & 0 & 4 & 4 & $0(0)$ & $4(100)$ & $4(100)$ & Not classified & Not classified & Not classified \\
\hline Black Drongo & 0 & 4 & 4 & $0(0)$ & $4(100)$ & $4(100)$ & Not classified & Not classified & Not classified \\
\hline Streak-eared Bulbul & 0 & 3 & 3 & $0(0)$ & $3(100)$ & $3(100)$ & Not classified & Not classified & Not classified \\
\hline Common Hoopoe & 2 & 0 & 2 & $2(100)$ & $0(0)$ & $2(100)$ & Not classified & Not classified & Not classified \\
\hline Blue Whistling Thrush & 1 & 1 & 2 & $1(100)$ & $1(100)$ & $2(100)$ & Not classified & Not classified & Not classified \\
\hline Sooty-headed Bulbul & 0 & 2 & 2 & $0(0)$ & $2(100)$ & $2(100)$ & Not classified & Not classified & Not classified \\
\hline Lesser Necklaced Laughingthrush & 0 & 2 & 2 & $0(0)$ & $2(100)$ & $2(100)$ & Not classified & Not classified & Not classified \\
\hline Racket-tailed Treepie & 1 & 0 & 1 & $1(100)$ & $0(0)$ & $1(100)$ & Not classified & Not classified & Not classified \\
\hline Asian Brown Flycatcher & 0 & 1 & 1 & $0(0)$ & $1(0)$ & $1(100)$ & Not classified & Not classified & Not classified \\
\hline Crested Goshawk & 0 & 1 & 1 & $0(0)$ & $1(100)$ & $1(100)$ & Not classified & Not classified & Not classified \\
\hline Sum & 194 & 277 & 471 & $170(36)$ & $262(94)$ & $432(91)$ & MD & SD & SD \\
\hline
\end{tabular}


Table 6. Comparison of the activity time of mammals and wild birds recorded from camera traps in the undisturbed and disturbed areas of species with large numbers recorded and the combined data of wildlife in the limestone mountain area of the central Thailand

\begin{tabular}{|c|c|c|c|c|c|c|}
\hline \multirow{2}{*}{ Species } & \multicolumn{2}{|c|}{ Undisturbed area } & \multicolumn{2}{|c|}{ Disturbed area } & \multicolumn{2}{|c|}{ Mardia-Watson-Wheeler Tests } \\
\hline & n & Hour (SD) & $\mathbf{n}$ & Hour (SD) & W & $\mathbf{P}$ \\
\hline \multicolumn{7}{|l|}{ Separated by species } \\
\hline Northern Pig-tailed Macaque & 2,556 & $12: 27(03: 56)$ & 760 & $12: 03(02: 33)$ & $312.26 * *$ & $<0.01$ \\
\hline Serow & 875 & $22: 00(06: 39)$ & 1,415 & $23: 21(03: 58)$ & $121.46^{* *}$ & $<0.01$ \\
\hline Red Jungle-fowl & 411 & $10: 09(04: 51)$ & 159 & $09: 49(04: 58)$ & $1.29^{\mathrm{ns}}$ & 0.52 \\
\hline Golden Jackal & 399 & $01: 42(09: 31)$ & 33 & $05: 26(04: 23)$ & $11.59 * *$ & $<0.01$ \\
\hline Malayan Porcupine & 266 & 02:16 (02:09) & 72 & $23: 38(02: 45)$ & $11.203 * *$ & $<0.01$ \\
\hline Variable Squirrel & 233 & 07:47 (03:02) & 226 & $11: 23(04: 51)$ & $94.21 * *$ & $<0.01$ \\
\hline Common Palm Civet & 62 & $23: 21(03: 19)$ & 119 & 00:08 (03:27) & $1.37^{\mathrm{ns}}$ & 0.50 \\
\hline Leopard Cat & 40 & $23: 05(06: 00)$ & 10 & $23: 14(03: 26)$ & $4.13^{\mathrm{ns}}$ & 0.13 \\
\hline Small Indian Mongoose & 33 & $10: 59(03: 37)$ & 22 & $09: 19(03: 58)$ & $3.97^{\mathrm{ns}}$ & 0.14 \\
\hline \multicolumn{7}{|l|}{ Combined data } \\
\hline All Mammalian species & 4586 & $11: 44(06: 05)$ & 2672 & $22: 52(09: 06)$ & $337.16^{* *}$ & $<0.01$ \\
\hline All Aves species & 463 & $11: 20(04: 37)$ & 653 & $12: 38(03: 37)$ & $93.458 * *$ & $<0.01$ \\
\hline
\end{tabular}

In the case of wild birds, the RAI in the disturbed area was significantly higher than in the undisturbed area, as well as the Shannon-Weiner index and the Evenness index in the disturbed area which were also higher. This is consistent with a study by $\mathrm{Tu}$ et al. (2020) that natural and open spaces in bird habitats play an important role in increasing the diversity and evenness of wild bird species in the area. In the disturbed area, even with some mining activities, some areas have been preserved, thereby promoting greater bird diversity in the area. Therefore, preserving some parts of the area as well as conducting restoration activities by land adjustment and reforestation after mining, preventing disturbance by leaving enough habitat area and improvement of water and mineral resources are activities that can contribute to the conservation of wildlife in the area.

In the case of the wild birds in this study, we focused only on wild birds that forage on the ground and can be recorded by camera traps, thus the number of bird species is less than the number from sightings or net trapping. For example, the wild bird diversity study in Padawan limestone area, Sarawak, Malaysia by Mansor et al. (2011) reported the number of wild bird species in the limestone mountain area from several study methods including direct observation and using mist-nets, finding at least 80 species of birds from 34 families. Therefore, further studies on wild birds using other methods should be conducted.

In this study, the Malayan Pangolin, one of the listed critically endangered species, was recorded, as well as other vulnerable species including Serow, Northern Pigtailed Macaque and the Rufous Limestone-babbler, an endemic species that is only found in the study area. Furthermore several important species, for example, Leopard Cat, Golden Jackal, Malayan Porcupine, Largetoothed Ferret Badger, Small Indian Civet, Common Palm Civet and Small Asian Mongoose were also recorded. The camera traps in 2 locations were also able to record images of the Elongated Tortoise )Indotestudo elongata) which is another critically endangered species listed by the IUCN (2021).
The comparison of the overall wildlife activity pattern recorded from the camera traps in the study showed that both mammals and birds avoid human activities and are more active during the quieter hours. It was also found that the activity patterns are significantly different within the two areas. However, different wildlife species respond differently to disturbance activities. The most obvious ones are the serow and the leopard cat. This is similar to the study by Cremonesi et al. (2021) who reported the variation in the activities of medium-sized mammals between disturbed habitats and undisturbed habitats in Myanmar in the form of human activity avoidance. Similarly, the results of this study showed that in the mining activity area, Serows and Leopard Cats have variations of the activity pattern and are strongly nocturnal, whereas, in the undisturbed areas the activity patterns are more cathemeral. In the wild birds, especially Red Junglefowl, there was no difference in the activity patterns between the two areas.

In conclusion, the results of the camera trap survey conducted in the limestone mountains of Saraburi province recorded 15 species of mammals from 6 orders, 12 families and 23 species of wild birds from 15 families 7 orders, adding up to a total of 38 species from 27 families, 13 orders. The results of the study record 15 species of mammals in the undisturbed area and 11 in the disturbed area. The Malayan Pangolin, Small Indian Civet and Greybellied Squirrel, as well as the Elongated Tortoise, were found in the undisturbed area, while the number of wild bird species in the disturbed areas was more than in the undisturbed area. It was also found that the overall abundance and diversity of mammals in the disturbed and undisturbed areas were similar, which is not in accordance with the hypothesis. However, for the wild bird species, the relative abundance was different between the two areas, with the higher value found in the mining area which is more open, while there was no significant difference in the diversity index of the wild birds in the two areas. This shows the importance of conservation in both areas, with and without disturbance activities. For the activity patterns of the wildlife, the results show many species of wildlife 
e.g., Malayan Pangolin, Serow, Northern Pig-tailed Macaque, Rufous Limestone-babbler, Elongated Tortoise, Golden Jackal, Leopard Cat, Large-toothed Ferret Badger, Small Asian Mongoose, Common Palm Civet, Small Indian Civet, Malayan Porcupine, etc. Therefore, it is important to recognize the importance of the area to preserve the natural resources that still exist. The management by conserving the natural areas in the limestone quarry activity areas as a wildlife refuge is important. Furthermore, the restoration, conditioning the area after mining, increasing water resources, food sources, public relations, education and training for youths in the form of a natural learning center for the natural restoration process as well as wildlife management in the limestone mountain area should be conducted. The size of the trapping area did not influence the number of species caught on camera. It is logistically most efficient to keep the trapping area as small as possible (Tobler et al. 2008), in this study the sampling area remains representative of the total habitat as much as possible.

\section{ACKNOWLEDGEMENTS}

The researchers would like to thank the Managing Director of The Siam Cement (Kaeng Khoi) Public Company Limited, the manager of the Limestone Mining Refurbishment Division and all related persons. Also, we thank Prof. Dr. Sakhan Teejuntuk, Department of Silviculture, Faculty of Forestry, Kasetsart University who facilitated, financial support and local data collection, as well as the Department of Forest Biology and the Faculty of Forestry for their support. We also would like to express our recognition to the Unit for Capital Development for Human Resource Development, Capital for Higher Education Development, Research, and Innovation Creation, Office of National Higher Education Science Research and Innovation Policy Council (NXPO) under the research project on the ecology of important wildlife in Khao Yai National Park for instruments. We would like to express our gratitude to the Dean of the Faculty of Forestry for his constant support.

\section{REFERENCES}

Alström P, Davidson P, Duckworth JW, Eames JC, Le TT, Nguyen C, Timmins R. 2010. Description of a new species of Phylloscopus warbler from Vietnam and Laos. Ibis 152 (1):145-168. DOI: 10.1111/j.1474-919X.2009. 00990.x

Balete DS, Heaney LR, Alviola P, Rickart EA. 2013. Diversity and distribution of small mammals in the Bicol Volcanic Belt of Southern Luzon Island, Philippines. National Museum of the Philippines: Journal of Natural History 1: 61-86.

BirdLife International. 2021. Species factsheet: Turdinus calcicola Downloaded from http://www.birdlife.org on 25/07/2021. Recommended citation for factsheets for more than one species: BirdLife International (2021) IUCN Red List for birds. Downloaded from http://www.birdlife.org on 25/07/2021.

Chung KF, Leong WC, Rubite RR, Repin R, Kiew R, Liu Y, Peng CI. 2014. Phylogenetic analyses of Begonia sect. Coelocentrum and allied limestone species of China shed light on the evolution of SinoVietnamese karst flora. Botanical Studies (Taipei, Taiwan) 55 (1): 115. DOI: $10.1186 / 1999-3110-55-1$
Clements R, Sodhi NS, Schilthuizen M, Ng PKL. 2006. Limestone Karsts of Southeast Asia: Imperiled Arks of Biodiversity. BioScience 56 (9): 733-742. DOI: 10.1641/0006-3568(2006)56[733:LKOSAI]2.0.CO;2

Cloyed CS, Cappelli LR, Tilson DA, Crawford JA, Dell AI. 2017. Using remote camera traps to assess mammal and bird assemblages across a complex environmental landscape. bioRxiv. Doi:10.1101/109538

Cremonesi G, Bisi F, Gaffi L, Zaw T, Naing H, Moe K, Aung Z, Mazzamuto MV, Gagliardi A, Wauters LA. 2021. Camera trapping to assess status and composition of mammal communities in a biodiversity hotspot in Myanmar. Animals 11 (880): 2-17 . DOI: 10.3390/ani1 1030880

Chen D, Chen HW. 2013. Using the Köppen classification to quantify climate variation and change: An example for 1901-2010. Environ. Dev. 6: 69-79. Doi:10.1016/j.envdev.2013.03.007

Day M, Urich P. 2000. An assessment of protected karst landscapes in Southeast Asia. Cave Karst Sci. 27 (2): 61-70.

Dehling JM. 2011. A new karst-dwelling species of Kalophrynus (Anura: Microhylidae) from Gunung Mulu National Park, Borneo, Malaysia. Zootaxa 2737 (1), 49-60. DOI: 10.11646/zootaxa.2737.1.4

Department of Meteorological 2020. Saraburi Province Climate Information. Climatological Centre, Sara Buri Province, Thailand. [in Thai]

Department of National Parks, Wildlife and Pant Conservation. 2018. Plant in Limestone Habitat. Bureau of Plant and Forest Research. Bangkok, Thailand. [in Thai]

Dias-Silva L, Duarte GT, Alves R, Pereira MJR, Paglia A. 2018. Feeding and social activity of insectivorous bats in a complex landscape: The importance of gallery forests and karst areas. Mamm Biol 88: 52-63. DOI: 10.1016/j.mambio.2017.11.005

Grismer LL, Wood PL, Thura MK, Quah ESH, Murdoch ML, Grismer MS, Herr MW, Lin A, Kyaw H. 2018. Three more new species of Cyrtodactylus (Squamata: Gekkonidae) from the Salween Basin of eastern Myanmar underscore the urgent need for the conservation of karst habitats. J. Nat. Hist. 52 (19-20): 1243-1294, DOI: 10.1080/00222933.2018.1449911

Grismer L, Wood PL, Poyarkov NA, Le MD, Karunarathna S, Chomdej S, Suwannapoom C, Qi S, Liu S, Che J, Quah ESH, Kraus F, Oliver PM, Riyanto A, Pauwels OSG, Grismer JL. 2021. Karstic landscapes are foci of species diversity in the world's third-largest vertebrate genus Cyrtodactylus Gray, 1827 (Reptilia: Squamata; Gekkonidae). Diversity 13 (5):183. DOI: 10.3390/d13050183

Grinang J. 2013. Fishes and Macroinvertebrates of Padawan Limestone, Sarawak, Malaysia. BJRST 3 (2): 1-14.

Harisha MN, Hosetti BB. 2010. Diversity and Distribution of Avifauna of Lakkavalli Range Forest, Bhadra Wildlife Sanctuary, Western Ghat, India. Ecoprint 16: 21-27. DOI: 10.3126/eco.v16i0.3469

Haase M, Schilthuizen M. 2007. A new Georissa (Gastropoda: Neritopsina: Hydrocenidae) from a limestone cave in Malaysian Borneo. J Molluscan Stud 73 (3): 215-221. DOI: 10.1093/mollus/eym020

Hua Z. 2020. Ecology and Biogeography of the Limestone Vegetation in Southern Yunnan. Xishuangbanna Tropical Botanical Garden, Mengla, Yunnan, China.

Hughes AC. 2017. Understanding the drivers of Southeast Asian biodiversity loss. Ecosphere 8 (1): 1-33. DOI: 10.1002/ecs2.1624

IUCN. 2014. Biodiversity management in the cement and aggregates sector: Integrated Biodiversity Management System (IBMS). IUCN, Gland, Switzerland.

IUCN. 2021. The IUCN Red List of Threatened Species. Version 2021-1. https://www.iucnredlist.org

Jansen PA, Forrester TD, McShea WJ. 2014. Protocol for Camera-trap Surveys of Mammals at CTFS-ForestGEO Sites. Smithsonian Tropical Research Institute, Center for Tropical Forest Science, Republic of Panama.

Kays R, Arbogast BS, Baker-Whatton M, Beirne C, Boone HM, Bowler M, Burneo SF, Cove MV, Ding P, Espinosa S, Gonçalves ALS, Hansen CP, Jansen PA, Kolowski JM, Knowles TW, Lima MGM, Millspaugh J, McShea WJ, Pacifici K, Parsons AW, Pease BS, Rovero F, Santos F, Schuttler SG, Sheil D, Si X, Snider M, Spironello WR. 2020. An empirical evaluation of camera trap study design: How many, how long and when?. Methods Ecol Evol 11 (6): 700713. DOI: $10.1111 / 2041-210 X .13370$.

Keim JL, Lele SR, DeWitt PD, Fitzpatrick JJ, Jenni NS. 2019. Estimating the intensity of use by interacting predators and prey using camera traps. J Anim Ecol 88 (5): 690-701. DOI: 10.1111/1365-2656.12960. 
Kovach Computing Services. 2011. Oriana Version 4 Users' Manual. Kovach Computing Services, Pentraeth, Wales, U.K.

Krebs CJ. 2014. Ecological Methodology, 3rd ed. New York. https://www.zoology.ubc.ca/ krebs/books.html

Kronfeld-Schor N, Bloch G, Schwartz WJ. 2013. Animal clocks: When science meets nature. Proceedings of the Royal Society B: Biological Sciences 280(1765): 20131354. DOI: 10.1098/rspb.2013.1354.

Latinne A, Surachit Waengsothorn S, Herbreteau V, Michau JR. 2011. Thai limestone karsts: an impending biodiversity crisis. In: Thai Society of Higher Education Institutes on Environment 4: 176-187. Proceeding of the 1st Environment Asia International Conference on Environmental Supporting in Food and Energy Security: Crisis and Opportunity. Bangkok, 22-25 March 2011. [Thailand]

Lekagul B, McNeely JA. 1988. Mammals of Thailand. Darnsutha Press, Bangkok.

Lekagul B, Round PD. 1991. A Guide to the Birds of Thailand Darnsutha Press, Bangkok.

Lillo EP, Fernando ES, Lillo MJR. 2019. Plant diversity and structure of forest habitat types on Dinagat Island, Philippines. J Asia-Pacific Biodivers. 12 (1): 83-105. DOI: 10.1016/j.japb.2018.07.003

Luu VQ, Bonkowski M, Nguyen TQ, Le MD, Schneider N, Ngo HT, Ziegler T. 2016. Evolution in karst massifs: Cryptic diversity among bent-toed geckos along the Truong Son Range with descriptions of three new species and one new country record from Laos. Zootaxa 4107 (2): 101-140. DOI: 10.11646/zootaxa.4107.2.1

Luu VQ, Nguyen TQ, Le MD, Bonkowski M, Ziegler T. 2017. A new karst dwelling species of the Gekko japonicus group (Squamata: Gekkonidae) from central Laos. Zootaxa 4263(1):179-193. DOI: 10.11646/zootaxa.4263.1.10

Mansor MS, Sah SA, Koon LC, Rahman MA. 2011. Bird species diversity in the padawan limestone area, Sarawak. Trop Life Sci Res 22 (2):6580.

Mardia KV. 1972. Statistics of Directional Data. Academic Press, London

Mo J, Ji Y, Xu H, Li D, Liu F. 2021. Camera-trapping survey on mammals and birds in a forest dynamic plot in Hainan Jianfengling National Nature Reserve. Biodiv Sci 29(6): 819-824. DOI: 10.17520/biods.2020350

Nazarov RA, Pauwels OSG, Konstantinov EL, Chulisov AS, Orlov NL, Poyarkov NA. 2018. A new karst-dwelling bent-toed gecko (Squamata: Gekkonidae: Cyrtodactylus) from Xiangkhoang Province, northeastern Laos. Zool Res 39 (3): 202-219. DOI: 10.24272/j.issn.2095-8137.2018.010.

O’Brien TG, Kinnaird MF, Wibisono HT. 2003. Crouching tigers, hidden prey: Sumatran tiger and prey populations in a tropical forest landscape. Anim Conserv 6 (2): 131-139. DOI 10.1017/S1367943003003172.

Ouboter PE, Kadosoe VS. 2016. Three years of continuous monitoring of the large terrestrial mammals of Brownsberg Nature Park, Suriname. Acad J Suriname 7: 643-660.
Palmer MS, Swanson A, Kosmala M, Arnold T, Packer C. 2018. Evaluating relative abundance indices for terrestrial herbivores from large-scale camera trap surveys. Afr J Ecol 56 (4): 791-803. DOI: 10.1111/aje.12566

Phutthai T, Hughes M. 2017. A new species of Begonia section Parvibegonia (Begoniaceae) from Thailand and Myanmar. Blumea 62: 26-28. DOI: 10.3767/000651917X695083.

Pielou EC. 1966. The measurement of diversity in different types of biological collections. J Theor Biol 13: 131-144. DOI: 10.1016/00225193(66)90013-0

Siam Cement Group. 2017. Rehabilitation of limestone mines, Rehabilitation of mines by biodiversity conservation. The Siam Cement (Kaeng Khoi) Company Limited, Sara Buri. [Thailand]

Steinbeiser CM, Kioko J, Maresi A, Kaitilia R, Kiffner C. 2019. Relative abundance and activity patterns explain method-related differences in mammalian species richness estimates. J Mammal 100 (1): 192-201. DOI: 10.1093/jmammal/gyy175

Sukmasuang R, Charaspet K, Panganta T, Pla-ard M, Khioesree N, Thongbanthum J. 2020. Diversity, abundance, activity period, and factors affecting the appearance of wildlife around the corridors between Khao Yai-Thap Lan National Parks, Thailand by camera $\begin{array}{llr}\text { trapping. } & \text { Biodiversitas } & 21 \text { : }\end{array}$ DOI: $10.13057 /$ biodiv/d210563.

TEAM 2008. Terrestrial Vertebrate Monitoring Protocol. v 3.0. Conservation International, Arlington, VA

Tobler MW, Carrillo-Percastegui SE, Pitman RL, Mares R, Powell G. 2008 An evaluation of camera traps for inventorying large and medium-sized terrestrial rainforest mammals. Anim Conserv 11 (3): 169-178. Doi: 10.1111/j.1469-1795.2008.00169.x

Tolentino PJS, Navidad JRL, Angeles MD, Fernandez AP, Villanueva ELC, Obena RDR, Buot Jr IE. 2020. Review: Biodiversity of forests over limestone in Southeast Asia with emphasis on the Philippines. Biodiversitas 21: 1597-1613. DOI: 10.13057/biodiv/d210441.

Tu HM, Fan MW, Ko JCJ. 2020. Different Habitat Types Affect Bird Richness and Evenness. Sci Rep 10: 1221(2020). DOI: 10.1038/s41598-020-58202-4.

UNESCO. 2021. Dong Phayayen-Khao Yai Forest Complex. UNESCO World Heritage Centre, New York. https://whc.unesco.org/en/list/590/

Van Schaik CP, Griffiths M. 1996. Activity periods of Indonesian rain forest mammals. Biotropica 28: 105-112

Woxvold IA, Duckworth JW, Timmins RJ. 2009. An unusual new bulbul (Passeriformes: Pycnonotidae) from the limestone karst of Lao PDR. Forktail 25 (25): 1-12.

Zaragozı B, Belda A, Gim'enez P, Navarro JT, Bonet A. 2015. Advances in camera-trap data management tools: Towards collaborative development and integration with GIS, Ecol Inform 30 (2015):6-15. DOI: 10.1016/j.ecoinf.2015.08.00 